\title{
Promising Information Technologies for Tax Purposes: International Trends in Software for Auditors
}

\author{
Larisa Petrovna Grundel, Nina Ilinishna Malis, Irina Aleksandrovna Zhuravleva, \\ Nadezda Petrovna Melnikova, Olga Valentinovna Mandroshchenko \\ Financial University under the Government of the Russian Federation, Moscow, Russia. \\ ORCIDs: 0000-0002-0291-9358 (Larisa), 0000-0001-6801-874X (Nina), 0000-0002-6772-4092 (Irina), \\ 0000-0001-7797-7942 (Nadezda), 0000-0002-2124-8561 (Olga)
}

\begin{abstract}
The use of specialized software in the field of e-audit is a recognized fact in world practice. However, at the same time, the specifics of the tax system of each state make it impossible to simply borrow such software.

The article describes the data analysis software used by fiscal authorities in conducting e-audits, as well as presents a comparative analysis of the specialized software used for eaudit.

The results of the study have shown that the specialized professional IT audit software named ACL Audit Exchange is a tool that currently provides great opportunities and can significantly simplify the audit process, namely, provide a sufficient level of support.
\end{abstract}

Keywords: information technologies, computer audit, electronic tax audit, specialized professional audit software.

\section{INTRODUCTION}

It is necessary to ensure the proper functioning of the electronic audit (e-audit) institution by creating appropriate conditions for the fulfillment of tax obligations by taxpayers and ensuring the protection of their rights and legitimate interests, achieving the highest level of coordination with the results of inspections, reducing the time and effort spent on providing relevant documentation, as well as simplifying the work of the Federal Tax Service of the Russian Federation [21-23].

The implementation of e-audit in Russia has resulted from the dynamic development of information technologies, significant progress in auditing, and practical world achievements in automating administrative processes, as well as increasing the effectiveness of tax control over the entire array of business operations performed by taxpayers $[24,25]$.

Today, the general trend in the employment of e-audit is the use of the information technology environment for interaction between fiscal authorities and taxpayers. At that, the problem of creating a multilevel security environment for data processing according to the principles of confidentiality, minimum privileges, and segregation of duties, as well as deep protection, and usability remains one of the main problems of e-audit. However, in addition to physical and hardware security, it is necessary to create a reliable information security environment to ensure that the confidentiality, integrity, and availability of data comply with the ISO 27001/2 international standards.

It should be emphasized that the emergence of e-audit, the stages of its implementation, and effectiveness, as well as the computerization of auditing processes, have been indirectly discussed in the works of both theorists and practitioners [1-3]. Also, some aspects of auditing in the context of using information technologies were considered in [4-6].

Tulvinschi M. [7] considers computer audits in the organizational aspect as the use of computers and contemporary information technologies for auditing, including checking financial statements and preparing an audit report. Liu R. [8] defines an e-audit as the use of computers and contemporary information technologies for auditing, including auditing financial statements and preparing an audit report, as well as providing related audit services. Besides, the term eaudit is interpreted as the use of information technologies by the auditor in the course of verifying information generated in the environment of the client's computer information system, based on risks assessment inherent in such an environment, etc. [9].

Based on the above, it is advisable to combine these formulations into one definition, namely: computer (electronic) audit is a check of accounting operations (and their sources/origin) of a business entity provided in electronic form using specialized software to determine their reliability, completeness, and compliance with current legislation [26, 27].

Note that conducting an audit in the context of using computer systems is regulated by international standards on auditing. Therefore, the implementation of a comprehensive e-audit necessarily involves conducting an in-depth analysis of the taxpayer's activities and financial situation based on accounting and financial statements [10].

It should be noted that various software products used for eaudit are available on the world market $[11,12]$. At that, two components of any software used in the e-audit can be distinguished: specialized software and control data. The first one is used to check the contents of files, and sometimes to restore accounting and tax records of a business entity, while the second one is used to check the correct functioning of computer programs [13]. Using, in particular, special software tools, regulatory authorities check, simulate, and analyze the accounting data contained in the standard audit file to determine their completeness, accuracy, legality, and reliability [14]. 
The composition and content of audit procedures are determined primarily by the list of tasks. Since each set of tasks consists of a set of special algorithms and programs grouped by a specific feature (audit objects or types of services), within each set one can use only the means required under particular conditions [15].

Since tax audit is one of the most effective methods of control by the fiscal authorities, it is advisable to implement appropriate software for e-audit (electronic checks) based on contemporary world developments, which will help to improve compliance by business entities with tax legislation and significantly save money and time of both fiscal authorities and taxpayers.

Analysis of the scientific literature [16-19] has shown that the following types of software used by fiscal authorities in foreign countries for e-auditing can be distinguished (Table 1).

Table 1. Characteristics of the data analysis software used by fiscal authorities for e-auditing

\begin{tabular}{|c|c|c|c|}
\hline No & $\begin{array}{l}\text { Software } \\
\text { type }\end{array}$ & Description & Characteristics \\
\hline 1 & $\begin{array}{l}\text { Generalized } \\
\text { Audit } \\
\text { Software } \\
\text { (GAS) }\end{array}$ & \begin{tabular}{|l|}
$\begin{array}{l}\text { General- } \\
\text { purpose } \\
\text { software }\end{array}$ \\
\end{tabular} & $\begin{array}{l}\text { The software allows the auditor } \\
\text { to test computer files, databases, } \\
\text { and computer networks in } \\
\begin{array}{ll}\text { compliance } & \text { with the } \\
\text { international standards }\end{array}\end{array}$ \\
\hline 2 & $\begin{array}{l}\text { Custom } \\
\text { Audit } \\
\text { Software } \\
\text { (CAS) }\end{array}$ & $\begin{array}{ll}\text { Special audit } \\
\text { software }\end{array}$ & $\begin{array}{l}\text { The software is necessary if the } \\
\text { computer systems of the client } \\
\text { who ordered the audit are } \\
\text { incompatible with the GAS } \\
\text { tools, or if the auditor needs to } \\
\text { perform certain tests that the } \\
\text { GAS tools do not provide }\end{array}$ \\
\hline 3 & Test Data & $\begin{array}{l}\text { Software tools } \\
\text { for testing data }\end{array}$ & $\begin{array}{l}\text { Test data are used by auditors } \\
\text { for testing software control of } \\
\text { client's computer applications } \\
\text { for data relevance, compliance } \\
\text { of procedures for their storage } \\
\text { and use with the information } \\
\text { security standards }\end{array}$ \\
\hline 4 & $\begin{array}{l}\text { Parallel } \\
\text { Simulation }\end{array}$ & $\begin{array}{l}\text { Parallel } \\
\text { simulation } \\
\text { software }\end{array}$ & $\begin{array}{l}\text { The auditor develops a } \\
\text { computer simulation to display } \\
\text { the production programs of the } \\
\text { audit client }\end{array}$ \\
\hline 5 & $\begin{array}{l}\text { Integrated } \\
\text { Test } \\
\text { Facility }\end{array}$ & $\begin{array}{l}\text { Integrated } \\
\text { testing tools }\end{array}$ & $\begin{array}{l}\text { The auditor tests the data } \\
\text { directly while the programs } \\
\text { (applications) are running }\end{array}$ \\
\hline
\end{tabular}

Note: compiled by the authors

The purpose of the article is to perform a comparative analysis of professional software in the field of the tax audit.

The research hypothesis is as follows: the effective use of specialized professional audit software depends not only on the professional skills of fiscal officials who work with it but also on the quality and convenience of supporting and maintaining this software.

Based on the research results, it can be concluded that the goal set in the study was achieved.

\section{METHODS}

General scientific and special research methods were used while conducting the work. General scientific methods served the methodological basis of the studies aimed at identifying promising information technologies used for tax purposes. The authors use abstract-logical methods, namely, analysis and synthesis, induction, and deduction.

Based on a comparative analysis of specialized professional audit software, a tool is proposed that currently provides great opportunities and can significantly simplify e-auditing, namely, provide a sufficient level of proper support.

At that, GAS solutions developed by Audit Command Language (ACL) (now called Galvanize) and Interactive Data Extraction and Analysis (IDEA) deserve special attention. Their developments called ACL Audit Exchange and IDEA (Version 11.1) are equipped with functionality for conducting various types of audits, both each type individually, as well as a full-scale holistic assessment.

These systems are specialized professional audit software intended for use when conducting e-audits.

To determine the qualitative characteristics of their functionality, the following software capabilities were analyzed:

- retrieval (copying) of data from the taxpayer's financial and accounting statements;

- their subsequent analysis using queries, stratification, sampling, identification of lost sequences, statistical analysis, calculations, search for data duplication, summary tables, cross-tabulation (counting events when categories are based on two or more variables, studying the relationship between two variables to explain them), etc.

To determine the convenience of the software in terms of support and maintenance, a comparative analysis was performed according to the CAAT-classification (IT tool for audit) aimed at determining whether automated support for the analysis of control objects defined by the COBIT 2019 standard was possible [20].

\section{RESULTS}

The conducted comparative analysis of ACL Audit Exchange (hereinafter ACL) and IDEA (Version 11.1) (hereinafter IDEA) has shown that the overall characteristics of the ACL and IDEA software are practically identical, and differ only in special tooling which is the basis of these two products. Thus, the ACL is designed based on the risks assessment of tax evasion, while the IDEA is designed based on the method of successive elimination (Table 2).

Therefore, it has been important to determine which software is the best to provide maximum support and automate the IT auditing. In this regard, a comparative analysis was carried out, according to the CAAT-classification (IT tool for audit) aimed at determining whether automated support for the analysis of control objects defined by the COBIT 2019 standard was possible [20] (Table 3). 
International Journal of Engineering Research and Technology. ISSN 0974-3154, Volume 13, Number 11 (2020), pp. $3977-3986$

(C) International Research Publication House. https://dx.doi.org/10.37624/IJERT/13.11.2020.3977-3986

Table 2. General characteristics of specialized software used for e-audit

\begin{tabular}{|c|c|c|}
\hline Indicator & ACL & IDEA \\
\hline Intended purpose & For conducting an e-audit & For conducting an e-audit \\
\hline Tooling & Risk assessment method & Method of successive elimination \\
\hline Data processing & $\begin{array}{l}\text { Allows combining data from different systems for } \\
\text { comparison and reconciliation }\end{array}$ & $\begin{array}{l}\text { Allows combining data from different systems } \\
\text { for comparison and reconciliation }\end{array}$ \\
\hline Data format & $\begin{array}{l}\text { Without restrictions (with subsequent implementation } \\
\text { of the generally accepted XBRL standard for financial } \\
\text { reporting) }\end{array}$ & $\begin{array}{l}\text { Without restrictions (with subsequent } \\
\text { implementation of the generally accepted XBRL } \\
\text { standard for financial reporting) }\end{array}$ \\
\hline The amount of data & No limits & No limits \\
\hline Data access & $\begin{array}{l}\text { In reading mode that does not allow changing data } \\
\text { during the e-audit and guarantees the integrity of } \\
\text { taxpayer's data }\end{array}$ & $\begin{array}{l}\text { In reading mode that does not allow changing } \\
\text { data during the e-audit and guarantees the } \\
\text { integrity of taxpayer's data }\end{array}$ \\
\hline Data protection & International information security standard ISO 27002 & $\begin{array}{l}\text { International information security standard ISO } \\
27002\end{array}$ \\
\hline
\end{tabular}

Note: compiled by the authors

So, as can be seen from Table 4, specialized professional audit software ACL is the tool that currently provides great opportunities and can significantly simplify IT audit, namely, provide a sufficient level of support (78\%).

\section{DISCUSSION}

Let us consider software data in more detail. The ACL software provides access to almost any data source, mostly without prior preparation or conversion, so it is fairly easy for an audit official to make queries and manipulate data in files.

The ACL software allows combining data from different systems for comparison and reconciliation, that is, to perform system integration. The auditor can create a general view of data stored in different files, and analyze them. The ACL has no limits to the total amount of data to be processed, including the size of the file, so this software product can simultaneously analyze millions of records.

The audit based on ACL software is performed in six stages.

1. Project planning (defining objectives and specifications). The ACL project looks like an electronic filing cabinet and is used by the auditor to store all related project elements, such as Tables, images, scripts, indexes, command logs, and folders (Fig. 1).

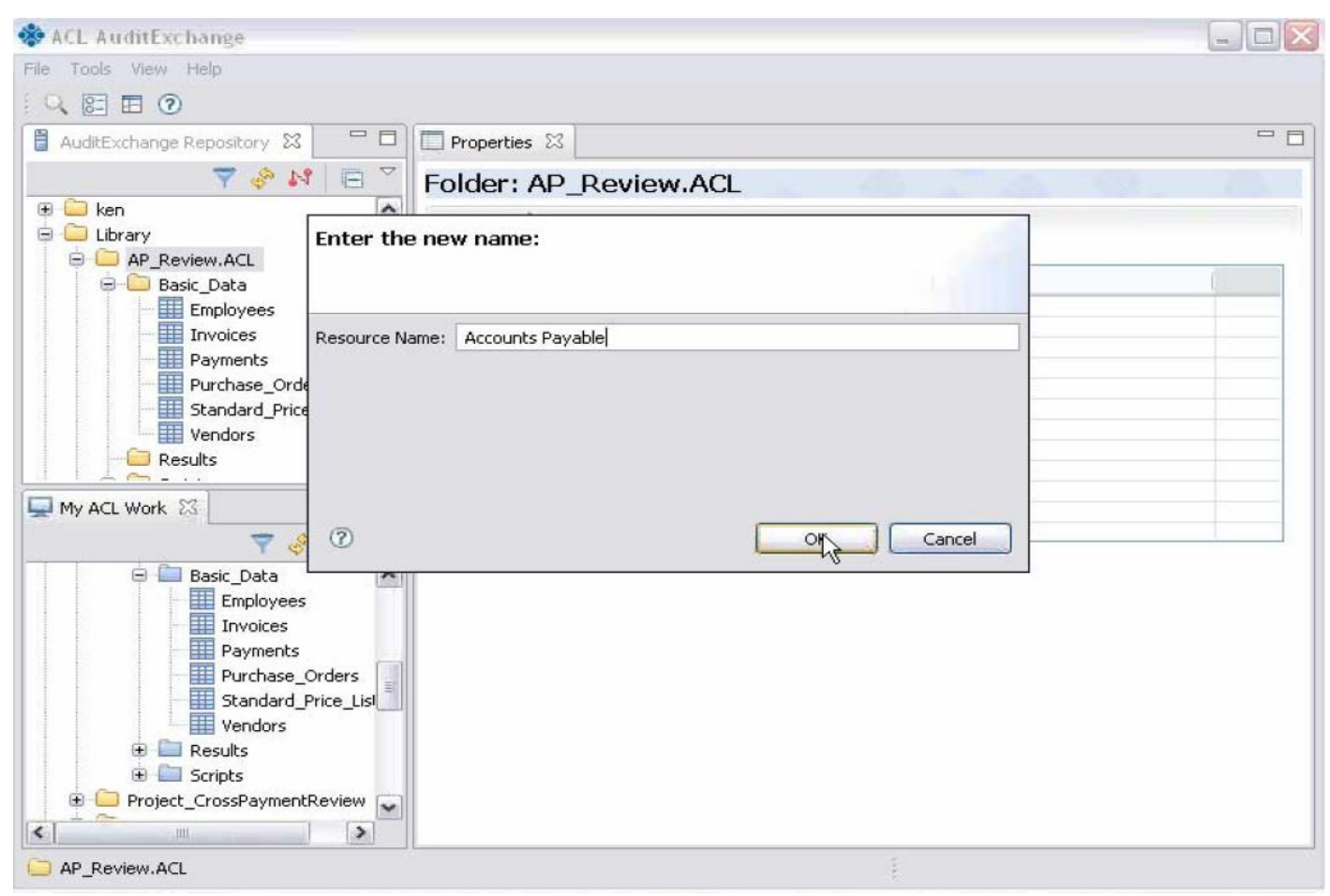

Figure 1. ACL: Project planning 
International Journal of Engineering Research and Technology. ISSN 0974-3154, Volume 13, Number 11 (2020), pp. $3977-3986$

(C) International Research Publication House. https://dx.doi.org/10.37624/IJERT/13.11.2020.3977-3986

Table 3. Comparative analysis of information methods to support IT audit

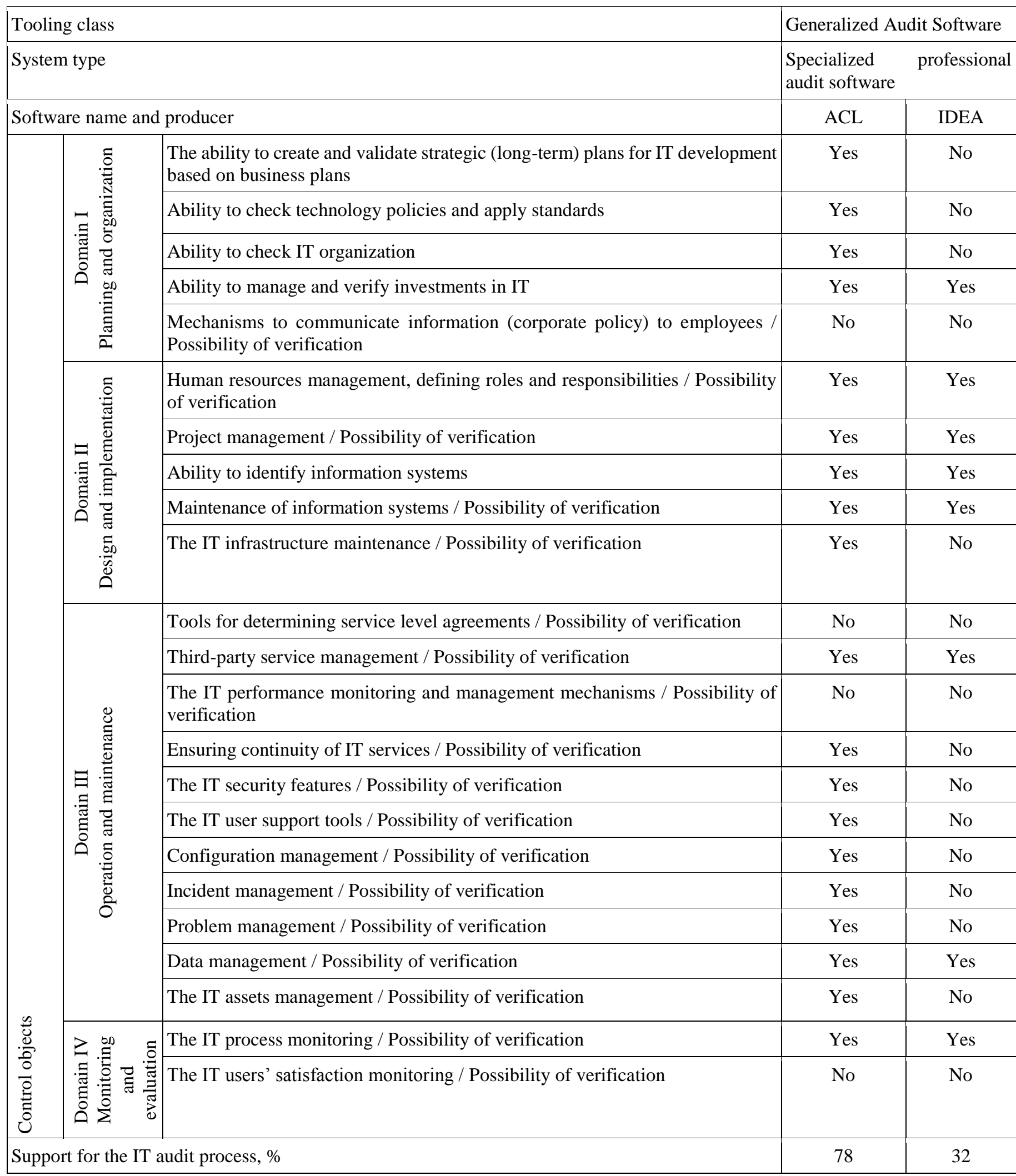

Note: compiled by the authors

2. Getting data (using the ACL data wizard to get data). For each data source that the auditor intends to analyze, it is necessary to add a new Table to the created ACL project. The
Table layout describes the structure and content of the source data and indicates their source, as well as describes the data in 
International Journal of Engineering Research and Technology. ISSN 0974-3154, Volume 13, Number 11 (2020), pp. $3977-3986$

(C) International Research Publication House. https://dx.doi.org/10.37624/IJERT/13.11.2020.3977-3986

each field, defines the fields that need to be analyzed, and indicates how to display and print this information (Figs. 2, 3).

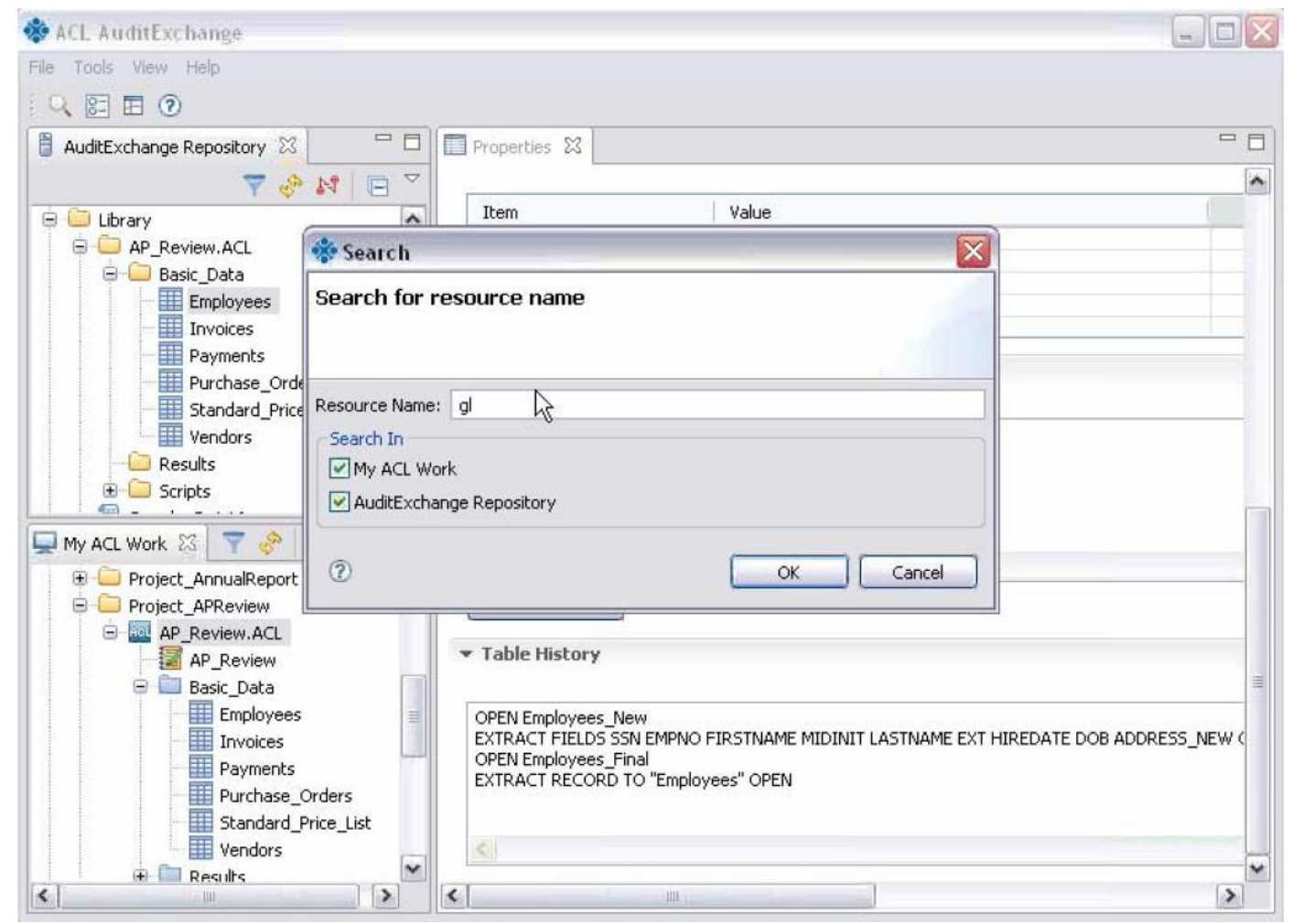

Figure 2. ACL: Searching database

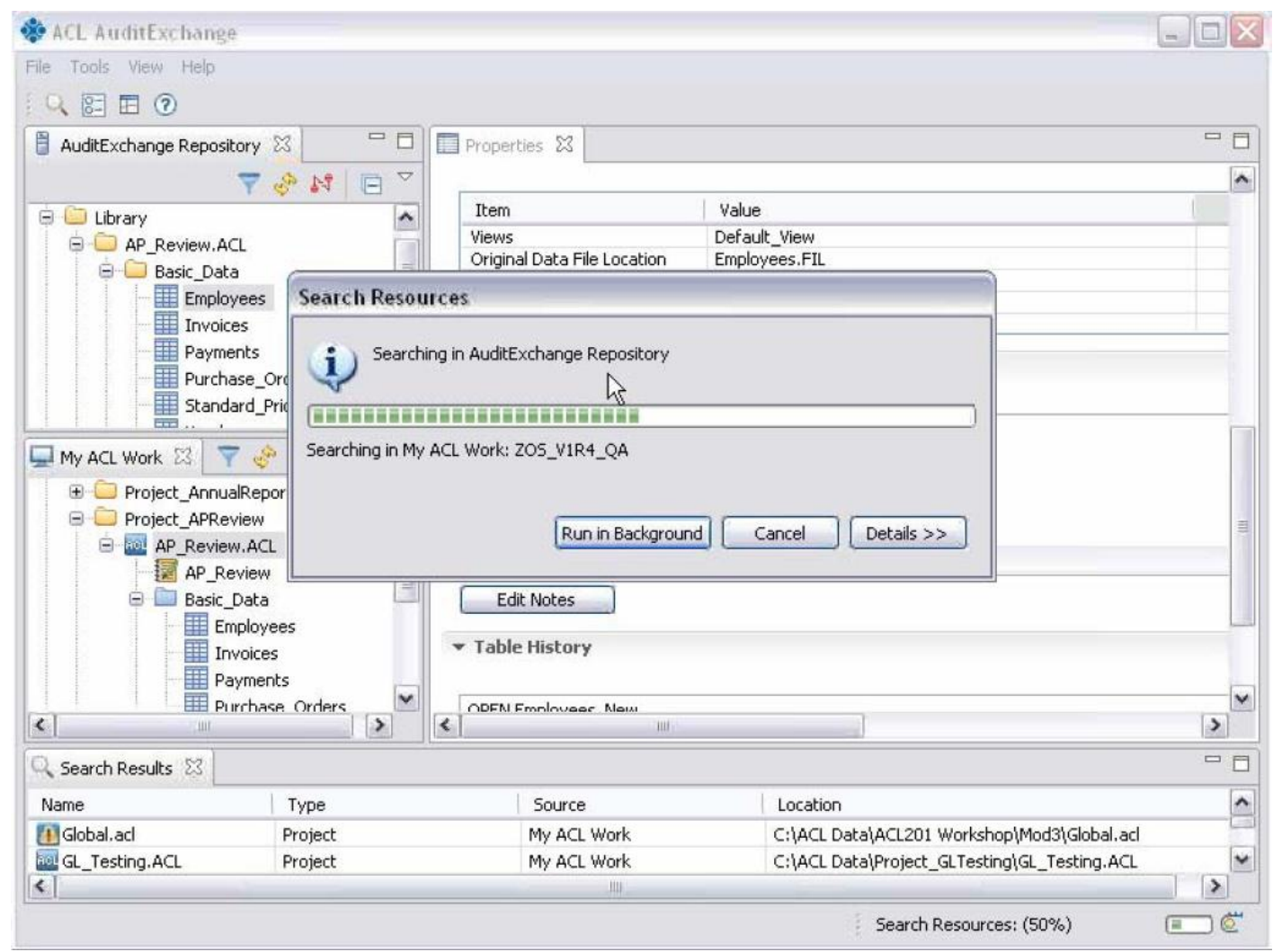

Figure 3. ACL: Getting data 
International Journal of Engineering Research and Technology. ISSN 0974-3154, Volume 13, Number 11 (2020), pp. $3977-3986$

(C) International Research Publication House. https://dx.doi.org/10.37624/IJERT/13.11.2020.3977-3986

3. Data access (using ACL data is integrated into the worksheets). The auditor can access server data using ACL and ACL Server Edition networks to work in a client/server configuration or run ACL Server Edition offline.

The ACL software allows the auditor to view the source files only in the reading mode that does not allow changing the data during the e-auditing, which, in turn, guarantees the integrity of taxpayer's data.
To describe the location and content of the source data, the ACL uses Tables. If the need to work on a new data source arises, a new Table is created by using the data definition wizard, as well as defining data manually. One can also edit the Table layout during the auditing to add, delete, or change the fields that need to be analyzed (Fig. 4).

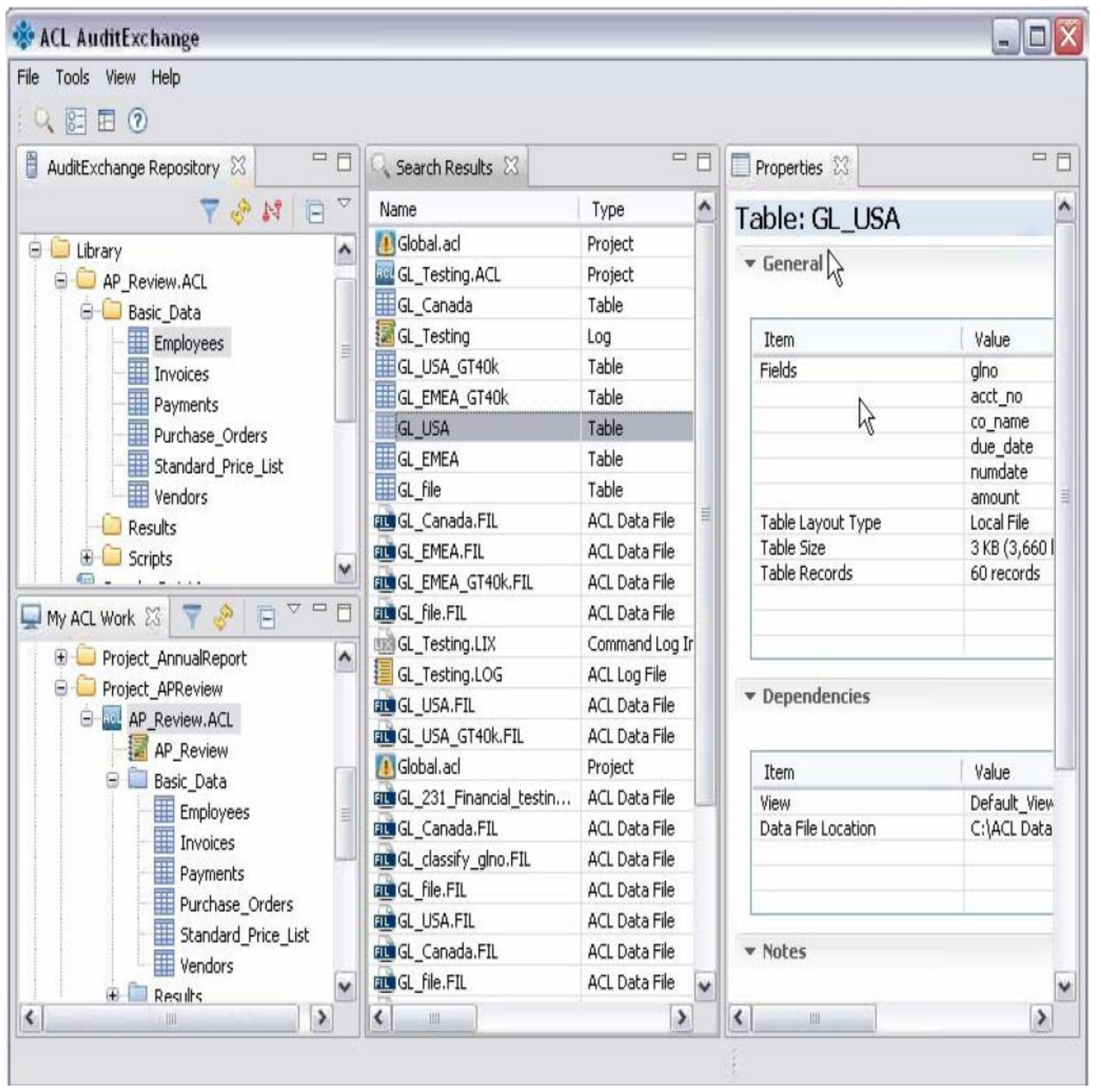

Figure 4. ACL: Data access

4. Checking data integrity (performing sample calculations and tests to make sure that the Tables are built correctly). Checks for errors are conducted in the active Table to ensure that the corresponding data comply with the Table format, and the presence of any error is defined using Verify command (Fig. 5). 
International Journal of Engineering Research and Technology. ISSN 0974-3154, Volume 13, Number 11 (2020), pp. $3977-3986$

(C) International Research Publication House. https://dx.doi.org/10.37624/IJERT/13.11.2020.3977-3986

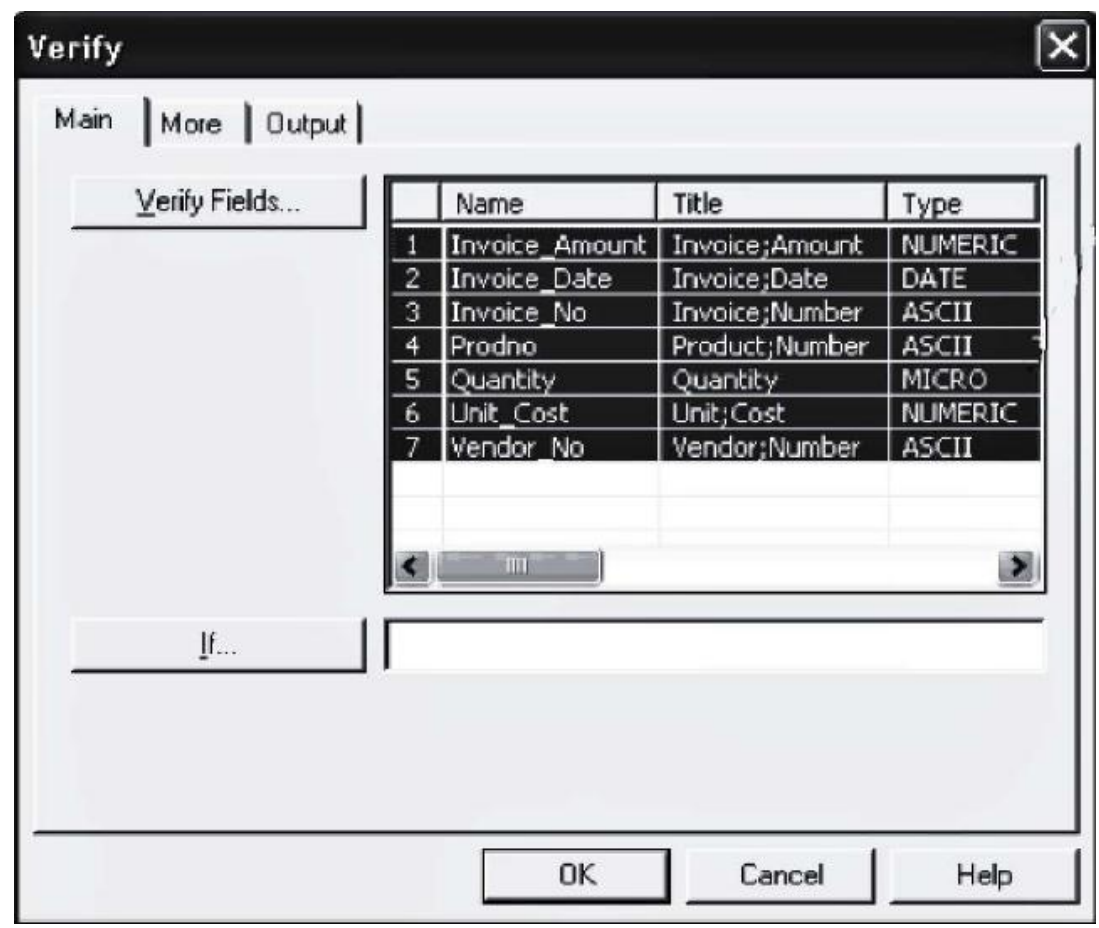

Figure 5. ACL: Data integrity check

5. Data analysis (determination of deviations). Digital analysis tools allow auditors to pay attention to possible deviations (anomalies) in large data sets. They do not prove that such an error or fraud exists but define a list of operations that require further study and analysis.

6. Report on the audit (recording audit results).

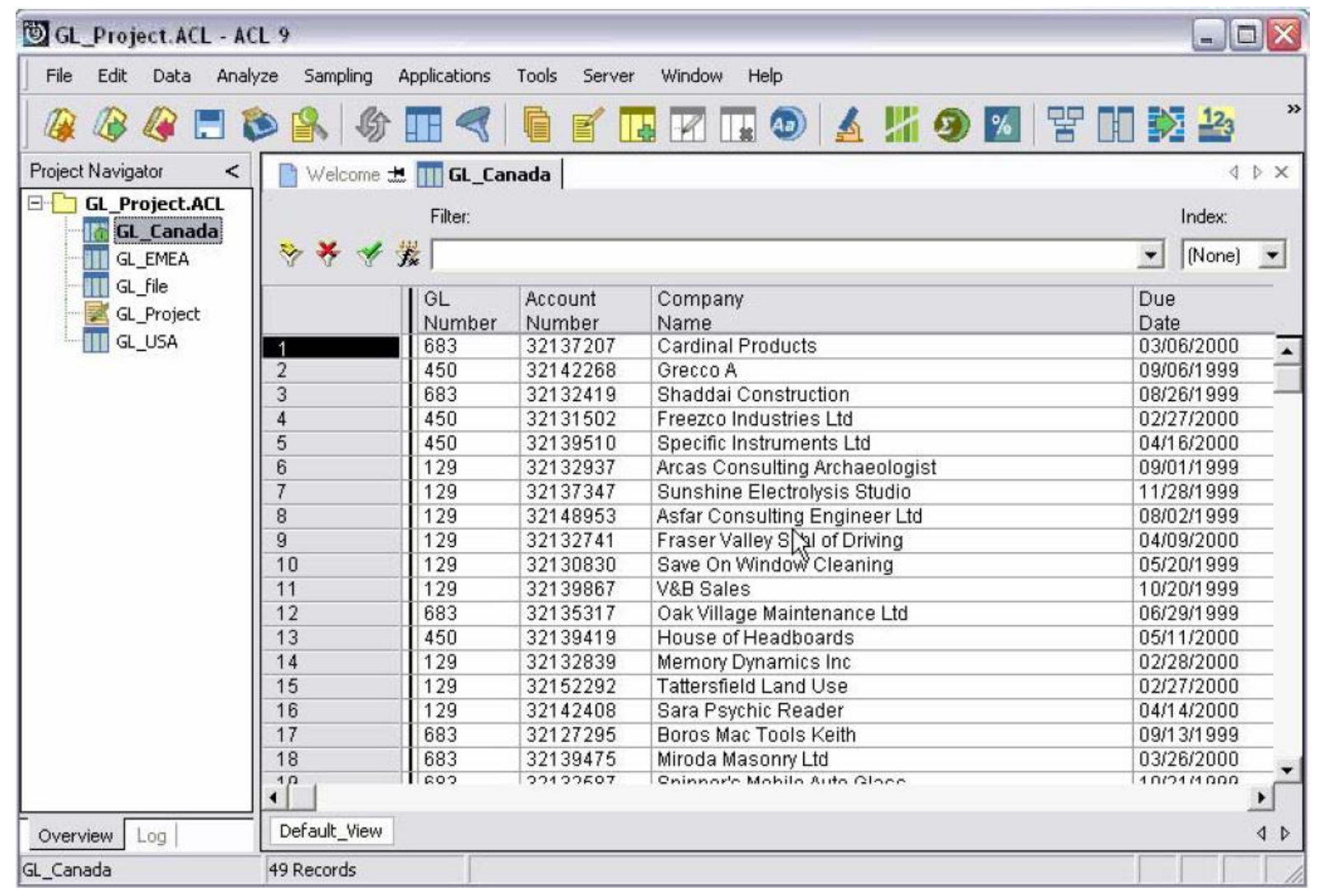

Figure 6. ACL: Preparing the audit report 
The IDEA software is a universal system that is a powerful and convenient tool for analyzing data generated by automated accounting systems. The IDEA software allows analyzing $100 \%$ of the taxpayer's data and guarantees their safety and integrity. At the same time, it is worth noting that one of the advantages of using this software is the ability to analyze large amounts of structured information - financial, economic, statistical, and accounting, presented in various formats. It also allows importing multiple data sets and viewing them as a whole, which allows conducting a comprehensive analysis of transactional data and establishing patterns and deviations.

Instead of standard programming macro, the IDEA allows using more than a hundred integrated tests that help auditors identify incorrect or suspicious transactions (large amounts, repetitive types of work, nonstandard operations), check the correctness of the balance, correspondence of accounts, compliance of material and financial accounting data and payment documents with accounting data.

The IDEA makes it possible to process data obtained from almost any standard accounting and office software. It is also worth emphasizing that the developers of the IDEA software indicate that this software can be introduced into the existing system which the fiscal authority already uses.

Standard options for using the functionality of the IDEA software are quite universal, capable of analyzing accounting data of various types (not only in the form of accounting entries but also, for example, chronological records of operational accounting systems and any Tables containing economic data).

Information concerning the buyers with whom the sales staff or agents dealt with, how many transactions they made with each buyer and for what total amounts, may be interesting for the auditor when analyzing to detect, for example, fraud. To do this, one can use the program function that allows toting key fields (Fig. 7).

As a result, the auditor gets a special database that contains records corresponding to the number of sellers hired by the company. Here, the VENDOR field contains the code of seller; the PAYEE field - the name of the buyer; the NO_OF_RECS field - the number of transactions; and the AMOUNT field the total amount for these transactions. Besides, here it is possible to view the records for each transaction in particular.

\begin{tabular}{|c|c|c|c|c|c|}
\hline \multirow{2}{*}{\multicolumn{2}{|c|}{ 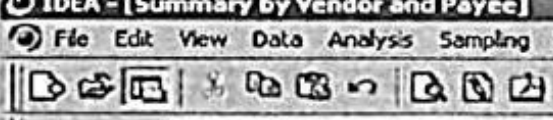 }} & \multicolumn{4}{|c|}{ Toots Whiow Heb } \\
\hline & & \multirow{2}{*}{ 国 $\mathbb{Q}^{\circ}$} & \multicolumn{3}{|c|}{ 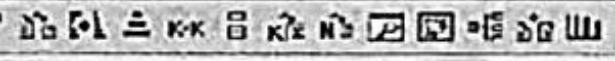 } \\
\hline 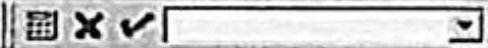 & No Index & & $\exists \square$ & \multicolumn{2}{|c|}{ No control totes $+\sqrt{100 \%}$} \\
\hline ( & $\square$ & VENDOR & PAYEE & NO OF RECS & AMOUNT \\
\hline \multirow{2}{*}{ E EN } & 1 & $A 128$ & A Meadow & $\begin{array}{r}19 \\
\hdashline \quad 19\end{array}$ & $471,412.23$ \\
\hline & 2 & $A 130$ & Adranced Consultin & 23 & 1.878 .687 .58 \\
\hline \multirow{5}{*}{ 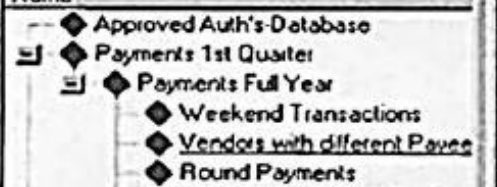 } & 3 & 8008 & A Meadow & $\frac{3}{1}$ & $145,922.34$ \\
\hline & 4 & 8008 & A Raid & 16 & $389,162.01$ \\
\hline & 5 & 8010 & Carter Bout & 20 & $515,245.40$ \\
\hline & 6 & C202 & CASHINC & 1 & $9,264.18$ \\
\hline & 7 & C202 & Cary S Matic & 20 & 720.66745 \\
\hline \multirow{7}{*}{ 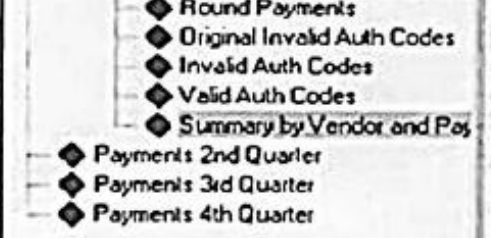 } & 8 & C202 & Cash Co & 1 & 13.867 .72 \\
\hline & 9 & C202 & CashFORUs & 1 & 49.033 .14 \\
\hline & 10 & C202 & F O R Cash Only & 1 & 30.850 .11 \\
\hline & 11 & C202 & Matl Cash & 1 & 6.242 .74 \\
\hline & 12 & C202 & Onlycash & 1 & $5,885.73$ \\
\hline & 13 & $\mathrm{C} 202$ & P Crook & 1 & $78,794.09$ \\
\hline & 14 & 0014 & Cary S Matic & 5 & $159,904.11$ \\
\hline & 15 & 0014 & Chimps Te aparty & G & 233.515 .32 \\
\hline & 16 & 0025 & Chimps Teaparty & 10 & $239,419.69$ \\
\hline & 17 & 0025 & Denise Bent & 14 & $459,473.87$ \\
\hline & 18 & $F 123$ & Denise Bent & 5 & $192,114.01$ \\
\hline & 19 & $F 123$ & Dick Tate & 16 & $559,344.07$ \\
\hline & 20 & $F 123$ & Edward Zot & 3 & $9,966.28$ \\
\hline & 21 & $F 128$ & Edward Zor & 2 & $287,588.98$ \\
\hline & 22 & $F 128$ & EmPayed & 16 & $433,698.70$ \\
\hline & 23 & $F 130$ & 1 Moore & 17 & $573,859.33$ \\
\hline & 24 & $F 130$ & A Meadow & 1 & $34,259.55$ \\
\hline & 25 & $F 130$ & Ein Payed & $\frac{6}{2}$ & $290,481.22$ \\
\hline & 26 & $F 130$ & Farmer & 17 & $366,372.72$ \\
\hline & 27 & 0010 & Farmer & 5 & $145,011,70$ \\
\hline & 28 & 0010 & Fixes & 20 & $525,696.12$ \\
\hline & 29 & G020 & Fixes & $\underline{5}$ & $305,465.90$ \\
\hline & 30 & & & 20 & 27.98 \\
\hline & 31 & Ho14 & Gus Main & 3 & $28,952.07$ \\
\hline & 213 & Den & $y<$ & & 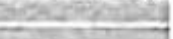 \\
\hline
\end{tabular}

Figure 7. Result of toting sales 
It is also worth noting that the creation of the considered specialized professional audit software is based on several international standards and best world practice.

\section{CONCLUSION}

Today, there are quite many software products on the market that can meet the ever-growing list of user requirements. In addition to the generally accepted requirements (efficiency of operations control tools, flexibility, ergonomics, the close association with accounting programs at the database level, availability of operational support from the developer), it is necessary to highlight requirements dictated by the contemporary development of information technologies, namely, the ability to organize work with the system remotely for visiting groups of auditors; ability to adjust the system as deeply as possible to the methodology adopted by the auditing firm, as well as standards for documenting audit and reporting rules; mandatory formation of the client's business projected growth; and high protection of the entire document flow of the auditing firm from unauthorized access. These requirements for the audit information system are of practical value when choosing computer audit software.

The results of the study have shown that the general characteristics of the ACL and IDEA software are almost identical, but differ only in the special tooling that makes up the basis of these software products. However, the specialized professional audit software ACL is a tool that today provides great opportunities and can significantly simplify the IT auditing, namely, provide a sufficient level of support and maintenance.

Thus, the research hypothesis has been confirmed that the effective use of specialized professional audit software depends not only on the professional skills of fiscal officials who work with it but also on the quality and convenience of supporting and maintaining this software.

\section{REFERENCES}

1. Viator, R.E., and Curtis, M.B., 1998. Computer auditor reliance on automated and non-automated controls as a function of training and experience. The Information Systems Journal, 12(1), pp. 19-30.

2. Braun, R.L., and Davis, H.E., 2003. Computer-assisted audit tools and techniques: Analysis and perspectives. Managerial Auditing Journal, 18(9), pp. 725-731.

3. Wang, Y.S., 2003. The adoption of electronic tax filing systems: An empirical study. Government Information Quarterly, 20(4), pp. 333-352.

4. Nikoloyuk, G.M., Marche, S., and McNiven, J., 2005. E-commerce impact on Canadian public sector audit practice. International Journal of Public Sector Management, 18(1), pp. 83-95.

5. Alshrouf, M., 2019. The effect of tax audit using the computer on tax non-compliance in Palestine. International Journal of Academic Research in Business and Social Sciences, 9(3), pp. 296-304.
6. Borthick, A.F., and Kiger, J.E., 2003. Designing audit procedures when evidence is electronic: The case of eticket travel revenue. Issues in Accounting Education, 18(3). pp. 275-290.

7. Tulvinschi, M. et al., 2007. Computer-assisted audit techniques. Journal of Applied Computer Science, 2, pp. 1043-1046.

8. Liu, R., 2011. The application of computer-aided audit for tax collection and management. Procedia Environmental Sciences, 2(11), pp. 50-54.

9. Josiah, M., and Izedonmi, P.F., 2013. Critical issues in international and e-audit evidence. International Journal of Management Sciences and Business Research, 2(3).

10. Rezaee, Z., Elam, R., and Sharbatoghlie, A., 2001. Continuous auditing: The audit of the future. Managerial Auditing Journal, 16(3), pp. 150-158.

11. Lin, W., and Wang, C., 2011. A selection model for auditing software. Industrial Management and Data Systems, 111(5), pp. 776-790.

12. Mahzan, N., and Lymer, A., 2014. Examining the adoption of computer-assisted audit tools and techniques - cases of generalized audit software use by internal auditors. Managerial Auditing Journal, 29(4), pp. 327-349.

13. Debreceny, R., Lee, S., Neo, W., and Toh, J.S., 2005. Employing generalized audit software in the financial services sector: Challenges and opportunities. Managerial Auditing Journal, 20(6), pp. 605-618.

14. Bierstaker, J., Janvrin, D., and Lowe, D.J., 2014. What factors influence auditors' use of computer-assisted audit techniques? Advances in Accounting, 30, pp. $67-$ 74.

15. Cao, M., Chychyla, R., and Stewart, T., 2015. Big data analytics in financial statement audits. Accounting Horizons, 29(2), pp. 423-429.

16. Elefterie, L., and Badea, G., 2016. The impact of information technology on the audit process. Economics, Management, and Financial Markets, 11(1), pp. 303-309.

17. Janvrin, D., Bierstaker, J., and Lowe, D.J., 2009. An investigation of factors influencing the use of computer-related audit procedures. Journal of Information Systems, 23(1), pp. 97-118.

18. Zaiceanu, A.M., Hlaciuc, E., and Lucan, A.N.C., 2015. Methods for risk identification and assessment in financial auditing. Procedia Economics and Finance, 32, pp. 595-602.

19. Rus, I., 2015. Technologies and methods for auditing databases. Procedia Economics and Finance, 26, pp. 991-999.

20. COBIT 2019. Framework: Introduction and Methodology. Schaumburg, IL: ISACA, 2018, 64 p.

21. Retrieved from https://journals.aserspublishing.eu/jarle/article/view/46 04

22. Retrieved from https://jssidoi.org/jesi/article/609 
International Journal of Engineering Research and Technology. ISSN 0974-3154, Volume 13, Number 11 (2020), pp. 3977-3986

○ International Research Publication House. https://dx.doi.org/10.37624/IJERT/13.11.2020.3977-3986

23. Retrieved from

http://revistainclusiones.com/gallery/10\%20VOL\%207

$\% 20 \mathrm{NUM} \%$

20ESPECIAL\%20CIENCIASENTIEMPODECAMBI

OS\%20JULIOSEPTIEMBREEE2020REVINCLUSIO

O.pdf

24. Retrieved from

https://journals.aserspublishing.eu/jemt/article/view/45 93

25. Retrieved from

http://www.spaceandculture.in/index.php/spaceandcult ure/article /view/686/338

26. Retrieved from

http://www.econjournals.com/index.php/ijeep/article/vi ew/7964

27. Izmailova, M.A. Major factors of achievement of quality of corporate management in the Russian medium-sized companies. Quality-Access to Success (ISSN15822559-Romania-Scopus) 